\title{
Utilization of Aliphatic Amides and Formation of Two Different Amidases by Alcaligenes eutrophus
}

\author{
By CORNELIUS G. FRIEDRICH* AND GABRIELE MITRENGA \\ Institut für Mikrobiologie der Universität, Grisebachstrasse 8, D-3400 Göttingen, \\ Federal Republic of Germany
}

(Received 12 December 1980; revised 5 February 1981)

\begin{abstract}
The utilization of aliphatic amides and their metabolism in the facultatively chemolithotrophic hydrogen bacterium Alcaligenes eutrophus has been investigated. This strain grew on fructose with formamide or acetamide as nitrogen sources, and these substrates induced formamidase. Ammonia repressed formamidase formation. Propionamide, butyramide and valeramide served as carbon and nitrogen sources and induced a different amidase, valeramidase. This enzyme was highly active with valeramide and less active with shorter acylamides but did not hydrolyse formamide. Valeramidase was subject to catabolite repression by fructose and succinate. Mutants altered in the regulation of amidase formation were isolated. A mutant able to grow with formamide and acetamide as carbon source formed formamidase constitutively, and this enzyme could not be repressed by ammonia in this mutant; its growth on formamide was autotrophic. A mutant able to grow with acetamide but not with formamide as carbon source was semi-constitutive for valeramidase; in this mutant the inducer specificity was altered and acetamide was the most potent inducer of valeramidase.
\end{abstract}

\section{INTRODUCTION}

The utilization of aliphatic amides as either carbon or nitrogen sources has been reported for several micro-organisms (Clarke, 1970) and is mainly mediated by amidases which carry out reactions:

$$
\mathrm{R} \cdot \mathrm{CO} \cdot \mathrm{NH}_{2}+\mathrm{H}_{2} \mathrm{O}=\mathrm{R} \cdot \mathrm{CO} \cdot \mathrm{OH}+\mathrm{NH}_{3}
$$

Detailed work on the biochemistry, the regulation and the genetics of amide utilization has been done with Pseudomonas aeruginosa by Clarke and collaborators (for reviews, see Clarke, 1970, 1972; Clarke \& Ornston, 1975). Formamide has attracted special interest as a substrate for micro-organisms able to utilize one-carbon compounds. The facultatively autotrophic Thiobacillus novellus was reported to grow on formamide as carbon source; however, formamidase activity could not be detected (Chandra \& Shetna, 1977). Pseudomonas AM1, a facultatively methylotrophic micro-organism, also grew with formamide as carbon source (Peel \& Quayle, 1961). In the present paper we describe the utilization of short-chain aliphatic amides as carbon or nitrogen sources by the facultatively chemolithoautotrophic hydrogen bacterium Alcaligenes eutrophus strain H16. We have investigated the formation of two different amidases, and have isolated mutants which show altered regulation of amidase formation and are thus able to use as carbon sources certain amides which are not used by the parent strain.

\section{METHODS}

Bacterial strains. Alcaligenes eutrophus strain H16 (ATCC 17699, DSM 428) and mutants derived from this strain were used throughout this study. 
Media and growth conditions. Autotrophic and heterotrophic growth was conducted at $30^{\circ} \mathrm{C}$. The media of Schlegel et al. (1961) were used for volumes up to $250 \mathrm{ml}$ in 1 litre baffled Erlenmeyer flasks. For enzyme studies, cells were cultivated in a less-buffered medium in a 12 litre laboratory fermenter with pH control as described by Friedrich et al. (1979). The $\mathrm{pH}$ of the medium was kept at 7.0 with $1.7 \mathrm{M}$-phosphoric acid when mutants grew with formamide or acetamide as carbon source. In this case the concentration of the aliphatic amides and other organic substrates was $0.4 \%(\mathrm{w} / \mathrm{v})$. When formate was used as carbon source or when the amides were provided as nitrogen source, the final concentration was $0.2 \%(w / v)$. For harvesting, cells were rapidly cooled to $4{ }^{\circ} \mathrm{C}$, washed once with $0.9 \%(\mathrm{w} / \mathrm{v}) \mathrm{NaCl}$ at $4{ }^{\circ} \mathrm{C}$ and stored at $-20{ }^{\circ} \mathrm{C}$.

Isolation of mutants. Mutants utilizing either formamide or acetamide as a carbon source were isolated by positive selection after mutagenesis by nitrite. Cells grown in $0.8 \%(\mathrm{w} / \mathrm{v})$ nutrient broth overnight were washed twice with $0.9 \%(\mathrm{w} / \mathrm{v}) \mathrm{NaCl}$, resuspended in $3 \mathrm{ml} 0.9 \%(\mathrm{w} / \mathrm{v}) \mathrm{NaCl}$ and incubated with shaking for $2 \mathrm{~h}$ at $30^{\circ} \mathrm{C}$. Then $2 \mathrm{ml} 0.6 \mathrm{M}$-sodium acetate buffer, $\mathrm{pH} 4.5$, and $2 \mathrm{ml} \mathrm{NaNO}$ solution $\left(3.4 \mathrm{mg} \mathrm{ml}^{-1}\right)$ were added and the mixture was incubated for $20 \mathrm{~min}$ at $30^{\circ} \mathrm{C}$. A $5 \mathrm{ml}$ portion of the suspension was added to $50 \mathrm{ml}$ $150 \mathrm{~mm}$-potassium phosphate buffer, $\mathrm{pH} 8 \cdot 1$. Cells from $20 \mathrm{ml}$ of this suspension were washed twice and resuspended in $10 \mathrm{ml} 0.9 \%(\mathrm{w} / \mathrm{v}) \mathrm{NaCl}$, and then portions of $1 \mathrm{ml}$ were added to $5 \mathrm{ml}$ fructose/ $\mathrm{NH}_{4} \mathrm{Cl}$ medium and incubated with shaking for $24 \mathrm{~h}$. Thereafter, cells were washed once, resuspended in $0.9 \%(\mathrm{w} / \mathrm{v}) \mathrm{NaCl}$ and $0.1 \mathrm{ml}$ samples were plated on mineral agar containing $0.1 \%(\mathrm{w} / \mathrm{v}) \mathrm{NH}_{4} \mathrm{Cl}$ and $0.4 \%(\mathrm{w} / \mathrm{v})$ formamide or acetamide. After $12 \mathrm{~d}$ incubation at $30^{\circ} \mathrm{C}$, pin-point colonies developed: the largest of these were picked after $24 \mathrm{~d}$, cloned on selective plates and maintained on fructose/mineral slants.

Enzyme assays. Cell extracts were obtained with a French press. The soluble fraction and membranes were prepared as described by Friedrich et al. (1979). All enzyme assays were conducted at $30^{\circ} \mathrm{C}$. One unit (U) of enzyme activity was defined as $1 \mu \mathrm{mol}$ substrate transformed $\min ^{-1}$.

Amidase activity was determined in assay mixtures (total volume $2.0 \mathrm{ml}$ ) containing $20 \mathrm{~mm}$-pyrophosphate buffer, pH $8.0,0.1$ to $2 \mathrm{mg}$ protein and $10 \mathrm{mM}$-aliphatic amide to start the reaction. Portions $(0.5 \mathrm{ml})$ were removed from the assay mixture at different times and subjected to the ammonia determination which terminated the enzyme reaction. The reaction rate of amidase was determined from the linear increase in ammonia released. Ammonia and aliphatic carboxylic acids were formed in equimolar amounts as determined by gas chromatography. Soluble formate dehydrogenase (EC 1.2.1.2) and membrane-bound formate dehydrogenase were determined as described by Friedrich et al. (1979). Ribulosebisphosphate carboxylase (EC 4.1.1.39) activity was measured by ribulose bisphosphate-dependent incorporation of ${ }^{14} \mathrm{CO}_{2}$ into acid-stable products as described by Bowien et al. (1976).

Ammonia, formamide and formate determination. Ammonia was determined in $0.5 \mathrm{ml}$ samples which were added to $2.5 \mathrm{ml}$ of a solution containing $0.106 \mathrm{M}$-phenol and $0.17 \mathrm{mM}$-nitroprusside. After the addition of $2.5 \mathrm{ml}$ $11 \mathrm{mM}$-hypochlorite in $0.125 \mathrm{M}-\mathrm{NaOH}$, the mixtures were incubated at $30^{\circ} \mathrm{C}$ for $30 \mathrm{~min}$ and the absorbance was read at $550 \mathrm{~nm}$ ( $1 \mathrm{~cm}$ path length cuvette) in a Zeiss PM4 spectrophotometer. Under these conditions $1 \mu \mathrm{mol}$ ammonia gave an absorbance of 1.35 ; standard curves were prepared daily.

Formamide was assayed in $0.5 \mathrm{ml}$ samples to which $0.5 \mathrm{ml} 2 \mathrm{M}$-hydroxylamine hydrochloride was added, followed by the addition of $0.5 \mathrm{ml} 5 \mathrm{M}-\mathrm{NaOH}$ and incubation for $30 \mathrm{~min}$ at $25^{\circ} \mathrm{C}$. Then $0.5 \mathrm{ml} 5 \mathrm{M}-\mathrm{HCl}$ was added followed by $1.0 \mathrm{ml} 0.37 \mathrm{M}$-ferric chloride in $1 \mathrm{M}-\mathrm{HCl}$. The mixture was incubated for $20 \mathrm{~min}$. To expel the gas bubbles formed, the assay mixtures were vigorously 'whirled' before reading the absorbance at $540 \mathrm{~nm}$. Under these conditions $1 \mu \mathrm{mol}$ formamide gave an absorbance of 0.23 .

Formate was determined colorimetrically by the method of Lang \& Lang (1972).

Protein was determined by the Lowry method.

\section{RES ULTS}

\section{Growth on aliphatic amides}

Alcaligenes eutrophus strain $\mathrm{H} 16$ grew well with either propionamide, butyramide or valeramide as nitrogen source. When these amides served as carbon sources, the specific growth rates were lower. Also, the cultures exhibited pronounced lag phases when not pregrown on the identical medium. Formamide and acetamide served only as nitrogen sources, the latter amide allowing only very slow growth. With succinate as carbon source, formamide was a poor nitrogen source (Table 1). The reaction products of formamide and acetamide hydrolysis were formate and acetate. Since $A$. eutrophus is able to grow on formate and acetate (Friedrich et al., 1979) but unable to utilize the respective amides as carbon sources, it was of interest to investigate whether this was due to the regulation of amidase formation. Mutants were isolated which were capable of growing with formamide and acetamide as sole source of carbon (Table 1). 
Table 1. Specific growth rates of Alcaligenes eutrophus with aliphatic amides as carbon or nitrogen sources

\begin{tabular}{|c|c|c|c|c|}
\hline \multirow{2}{*}{$\begin{array}{c}\text { Carbon } \\
\text { source } \\
(0.4 \%, \mathrm{w} / \mathrm{v})\end{array}$} & \multirow{2}{*}{$\begin{array}{c}\text { Nitrogen } \\
\text { source } \\
(0.2 \%, \mathrm{w} / \mathrm{v})\end{array}$} & \multicolumn{3}{|c|}{ Specific growth rate $\left(\mathrm{h}^{-1}\right)$} \\
\hline & & $\begin{array}{c}\text { Strain } \\
\text { H16 }\end{array}$ & $\begin{array}{l}\text { Strain } \\
\text { FH10 }\end{array}$ & $\begin{array}{l}\text { Strain } \\
\text { FH11 }\end{array}$ \\
\hline Fructose & $\mathrm{NH}_{4} \mathrm{Cl}$ & 0.29 & 0.30 & 0.27 \\
\hline Fructose & Formamide & 0.18 & 0.23 & 0.17 \\
\hline Fructose & Acetamide & 0.07 & 0.10 & 0.08 \\
\hline Fructose & Propionamide & 0.27 & 0.19 & 0.26 \\
\hline Fructose & Butyramide & 0.26 & ND & ND \\
\hline Fructose & Valeramide & 0.24 & ND & ND \\
\hline Fructose & $\begin{array}{l}\text { Formamide } \\
+\mathrm{NH}_{4} \mathrm{Cl}\end{array}$ & 0.31 & ND & ND \\
\hline Succinate & $\mathrm{NH}_{4} \mathrm{Cl}$ & 0.46 & ND & ND \\
\hline Succinate & Formamide & 0.09 & ND & ND \\
\hline Formamide & $\mathrm{NH}_{4} \mathrm{Cl}$ & NG & 0.14 & NG \\
\hline Acetamide & $\mathrm{NH}_{4} \mathrm{Cl}$ & NG & 0.04 & 0.06 \\
\hline Propionamide & $\mathrm{NH}_{4} \mathrm{Cl}$ & 0.22 & 0.14 & 0.26 \\
\hline Butyramide & $\mathrm{NH}_{4} \mathrm{Cl}$ & 0.21 & 0.25 & 0.46 \\
\hline Valeramide & $\mathrm{NH}_{4} \mathrm{Cl}$ & 0.15 & ND & ND \\
\hline Propionamide & $\mathrm{NH}_{4} \mathrm{Cl}$ & 0.29 & ND & ND \\
\hline
\end{tabular}

ND, Not determined; NG, no growth.

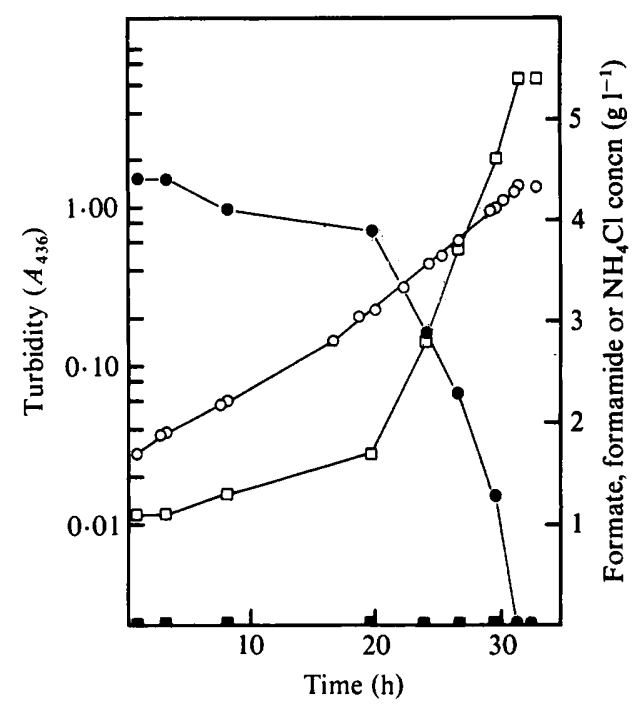

Fig. 1. Growth of Alcaligenes eutrophus strain FH10 on formamide as the sole carbon source. Growth was studied in a 10 litre laboratory fermenter aerated as indicated in Methods. Growth (O); concentrations of formamide $(\mathrm{O}), \mathrm{NH}_{4} \mathrm{Cl}(\square)$ and formate $(\square)$ in the culture medium.

Strain FH10, selected for formamide utilization, represented a rare type of mutant. This strain was also able to grow with acetamide as carbon source. Mutants like strain FH11 were selected for acetamide utilization and were obtained with approximately 20-fold higher frequency than those selected on formamide agar. They were unable to grow with formamide as carbon source (Table 1). Acetamide, either as carbon or as nitrogen source, allowed only slow growth of both types of mutants. Strain FH10 grew slower with propionamide as carbon 
Table 2. Enzymes of formamide utilization in Alcaligenes eutrophus

Cells were grown with $\mathrm{pH}$ control, harvested and extracts were prepared and assayed as described in Methods.

\begin{tabular}{|c|c|c|c|c|c|c|}
\hline \multirow[b]{3}{*}{ Strain } & \multirow{3}{*}{$\begin{array}{c}\text { Carbon } \\
\text { source } \\
(0.4 \%, \mathrm{w} / \mathrm{v})\end{array}$} & \multirow{3}{*}{$\begin{array}{c}\text { Nitrogen } \\
\text { source } \\
(0.2 \%, \mathrm{w} / \mathrm{v})\end{array}$} & \multicolumn{4}{|c|}{ Specific activity $\left[U(\mathrm{mg} \text { protein })^{-1}\right]$} \\
\hline & & & \multicolumn{2}{|c|}{ Formate dehydrogenase } & \multirow[b]{2}{*}{ Formamidase } & \multirow{2}{*}{$\begin{array}{l}\text { Ribulose- } \\
\text { bisphosphate } \\
\text { carboxylase }\end{array}$} \\
\hline & & & Soluble & Particulate & & \\
\hline H16 & Fructose & $\mathrm{NH}_{4} \mathrm{Cl}$ & 0.003 & 0.008 & 0 & 0.036 \\
\hline H16 & Formate & $\mathrm{NH}_{4} \mathrm{Cl}$ & 0.286 & 0.132 & 0.001 & 0.276 \\
\hline $\mathrm{H} 16$ & Fructose & Formamide & 0.028 & 0.001 & 0.048 & 0.054 \\
\hline FH10 & Fructose & $\mathrm{NH}_{4} \mathrm{Cl}$ & 0.003 & 0.011 & 1.900 & 0.029 \\
\hline $\mathrm{FH} 10$ & Formamide & $\mathrm{NH}_{4} \mathrm{Cl}$ & 0.712 & 0.209 & 1.520 & 0.384 \\
\hline
\end{tabular}

or nitrogen source than the parent strain on the same media. Strain FH11 grew rather fast with propionamide or butyramide as carbon source (Table 1).

\section{Autotrophic growth on formamide}

Strain FH10 utilized formamide as carbon source. Ammonia was released into the medium but no formic acid was excreted (Fig. 1). The molar growth yield $\left(Y_{\mathrm{m}}\right)$ was $3.15 \mathrm{~g}$ dry cell wt (mol formamide) $)^{-1}$ compared with a $Y_{\mathrm{m}}$ with formate of $2.35 \mathrm{~g} \mathrm{~mol}^{-1}$ (Friedrich et al., 1979). Since $A$. eutrophus is able to grow autotrophically on formate, it was of interest to know whether the carbon of formamide was assimilated via the Calvin cycle or via another pathway permitting higher growth yields (Goldberg, 1976).

Both the soluble and the membrane-bound formate dehydrogenases as well as ribulosebisphosphate carboxylase were formed during growth of strain FH10 on formamide (Table 2). These enzymes were also formed by the parent strain during growth on formate. With fructose as substrate, ribulosebisphosphate carboxylase was formed at up to $15 \%$ of its activity in autotrophically grown cells. The results given in Table 2 demonstrate that the mutant formed formamidase constitutively. The product of formamide hydrolysis, formate, induced the formate dehydrogenases and the key enzymes of the Calvin cycle (Table 2). This was enzymic evidence for autotrophic growth of the mutant strain on formamide. It should be noted that strain $\mathrm{FH} 10$ grown on formamide as carbon source contained 2.5 times more activity of the soluble formate dehydrogenase than did the parent strain grown on formate. It is possible that strain FH10 preferentially oxidized the formate generated from formamide by the soluble enzyme which yields NADH while the membrane-bound formate dehydrogenase is unable to reduce pyridine nucleotides. This would explain the higher molar growth yield of strain FH10 on formamide compared with the growth yield of the parent strain with formate as carbon source.

\section{Amidase activities and substrate specificity}

Amidase activities in extracts of cells grown with various aliphatic amides either as carbon or as nitrogen source were determined with amides of the homologous series from formamide to valeramide. During growth with fructose and formamide, A. eutrophus $\mathrm{H} 16$ formed an intermediate level of formamidase activity and trace activities reacting with longer-chain aliphatic amides (Table 3). With acetamide as nitrogen source these amidase activities were 10 times higher. With succinate as carbon source and formamide as nitrogen source no significant amidase activity could be detected. In crude extracts of cells grown with fructose as carbon source and formamide or acetamide as nitrogen source, the ratio of amidase activities with formamide, acetamide, propionamide, butyramide and valeramide as enzyme substrates was about $100: 3: 4 \cdot 5: 2 \cdot 5: 2$. This ratio changes when propionamide, butyramide or valeramide served as nitrogen source and was about $0: 4: 25: 45: 100$ (Table 3). However, 
Table 3. Amidase activities of Alcaligenes eutrophus H16 grown with aliphatic amides as nitrogen source

The carbon source was $0.4 \%(w / v)$ fructose.

\begin{tabular}{lccccc} 
& \multicolumn{5}{c}{ Amidase specific activity [U (mg protein) ${ }^{-1}$ ] } \\
\cline { 2 - 6 } \multicolumn{1}{c}{$\begin{array}{c}\text { Nitrogen source } \\
(0.2 \%, \mathrm{w} / \mathrm{v})\end{array}$} & Formamide & Acetamide & $\begin{array}{c}\text { Amidase substrate: } \\
\text { Propionamide }\end{array}$ & Butyramide & Valeramide \\
$\mathrm{NH}_{4} \mathrm{Cl}$ & 0 & 0 & 0.002 & 0.004 & 0.008 \\
Formamide & 0.098 & 0.002 & 0.003 & 0.001 & 0.001 \\
Formamide $+\mathrm{NH}_{4} \mathrm{Cl}$ & 0.001 & 0.002 & 0.002 & 0.006 & 0.010 \\
Acetamide & 0.999 & 0.024 & 0.048 & 0.024 & 0.018 \\
Propionamide & 0 & 0.002 & 0.029 & 0.081 & 0.179 \\
Butyramide & 0 & 0 & 0.043 & 0.106 & 0.142 \\
Valeramide & 0 & 0 & 0.004 & 0.007 & 0.014 \\
Formamide & 0.005 & 0 & 0.001 & 0 & 0.001
\end{tabular}

* Carbon source was $0.4 \%(\mathrm{w} / \mathrm{v})$ sodium succinate.

Table 4. Amidase activities of Alcaligenes eutrophus H16 grown with aliphatic amides as carbon source

The nitrogen source was $0 \cdot 2 \%(\mathrm{w} / \mathrm{v}) \mathrm{NH}_{4} \mathrm{Cl}$.

\begin{tabular}{lccccc} 
& \multicolumn{4}{c}{ Amidase specific activity [U (mg protein) $\left.{ }^{-1}\right]$} \\
\cline { 2 - 6 } \multicolumn{1}{c}{$\begin{array}{c}\text { Carbon source } \\
(0.4 \%, \mathrm{w} / \mathrm{v})\end{array}$} & Formamide & Acetamide & $\begin{array}{c}\text { Amidase substrate: } \\
\text { Propionamide }\end{array}$ \\
Propionamide & 0 & 0.004 & 0.060 & 0.155 & 0.316 \\
Butyramide & 0 & 0.001 & 0.007 & 0.021 & 0.043 \\
Valeramide & 0 & 0 & 0.002 & 0.005 & 0.009 \\
Propionamide + succinate & 0 & 0.001 & 0.002 & 0.002 & 0.003 \\
Propionamide + fructose & 0 & 0.001 & 0.012 & 0.027 & 0.058
\end{tabular}

the specific activity obtained with valeramide as enzyme substrate decreased with increasing chain length of the amide used as nitrogen source. Minor amidase activities reacting with butyramide and valeramide were found in extracts from cells grown in the absence of acylamides or on formamide plus $\mathrm{NH}_{4} \mathrm{Cl}$.

Propionamide, butyramide and valeramide could serve as carbon source to A. eutrophus (Table 1). During growth on these amides, the amidase activities formed reacted with the different acylamides in the same ratio as observed in extracts from cells grown with propionamide and longer chain acylamides as nitrogen source (Table 4). When succinate was included in the medium as an alternative carbon source to propionamide, almost no amidase activity was observed. The addition of fructose to the medium caused a less severe repression and allowed the formation of about $20 \%$ of the activity obtained with propionamide alone (Table 4). Neither formamidase nor valeramidase activity was observed when formate, acetate, propionate or butyrate served as carbon source and $\mathrm{NH}_{4} \mathrm{Cl}$ as nitrogen source (results not shown).

\section{Enzymic characterization of mutants}

Strain FH10 could grow on formamide or acetamide as carbon source (Table 1). Formamidase activity was formed at a high level when formamide was the carbon source. It was also formed when fructose was the carbon source and $\mathrm{NH}_{4} \mathrm{Cl}$ the nitrogen source (Tables 2 and 5). Thus, formamidase activity was formed constitutively by strain FH10. 
Table 5. Amidase activities of mutants of Alcaligenes eutrophus grown with aliphatic amides as carbon or nitrogen source

\begin{tabular}{|c|c|c|c|c|c|c|c|}
\hline \multirow[b]{2}{*}{ Strain } & \multirow{2}{*}{$\begin{array}{c}\text { Carbon } \\
\text { source } \\
(0.4 \%, w / v)\end{array}$} & \multirow{2}{*}{$\begin{array}{c}\text { Nitrogen } \\
\text { source } \\
(0.2 \%, w / v)\end{array}$} & \multicolumn{5}{|c|}{ Amidase specific activity $\left[\mathrm{U}(\mathrm{mg} \text { protein })^{-1}\right]$} \\
\hline & & & Formamide & Acetamide & $\begin{array}{c}\text { Amidase substrate } \\
\text { Propionamide }\end{array}$ & Butyramide & Valeramide \\
\hline FH10 & Formamide & $\mathrm{NH}_{4} \mathrm{Cl}$ & $1 \cdot 373$ & 0.034 & 0.074 & 0.034 & 0.023 \\
\hline FH10 & Fructose & $\mathrm{NH}_{4} \mathrm{Cl}$ & 0.934 & 0.025 & 0.045 & 0.025 & 0.018 \\
\hline FH 10 & Fructose & Propionamide & 1.009 & 0.023 & 0.033 & 0.020 & 0.018 \\
\hline FH11 & Fructose & $\mathrm{NH}_{4} \mathrm{Cl}$ & 0 & 0.005 & 0.044 & 0.114 & 0.242 \\
\hline FH11 & Acetamide & $\mathrm{NH}_{4} \mathrm{Cl}$ & 0 & 0.014 & $0 \cdot 160$ & 0.455 & 0.928 \\
\hline FH 11 & Fructose & Formamide & 0.048 & 0.006 & 0.077 & 0.200 & 0.507 \\
\hline
\end{tabular}

Propionamide as nitrogen source led to an increased formation of valeramidase activity in the parent strain (Table 3) but not in strain FH10 (Table 5).

Strain FH11 was able to grow with acetamide but not with formamide as carbon source (Table 1). Intermediate valeramidase activities of $0.24 \mathrm{U}$ (mg protein) ${ }^{-1}$ and no formamidase activity were observed in fructose $/ \mathrm{NH}_{4} \mathrm{Cl}$-grown cells. When acetamide was provided as carbon source the valeramidase activity was high. With formamide as nitrogen source a low formamidase activity was observed besides an intermediate level of valeramidase (Table 5).

\section{DISCUSSION}

The ratios of amidase activities with different amides as enzyme substrates as observed during growth of $A$. eutrophus on various acylamides provided evidence for two aliphatic amidases. One was specific for formamide but also slightly active with longer-chain acylamides; this enzyme was called formamidase. The other enzyme was not active with formamide but increasingly active with acylamides of increasing chain length. Among the substrates tested valeramide resulted in the highest activity, and the enzyme was therefore designated valeramidase. The two amidases differed not only with respect to their substrate specificity but also with respect to the regulation of their formation. Formamidase was only formed when formamide or acetamide served as nitrogen source. Formamidase was completely repressed by ammonia and also subject to catabolite repression by succinate (Table 3).

The growth rate with acetamide was very low compared with that obtained with formamide. This low growth rate was probably due to the low activity of formamidase with acetamide as enzyme substrate. The level of formamidase activity in cells grown with acetamide as nitrogen source was about 10 -fold higher than with formamide as nitrogen source. Therefore, acetamide was considered to be a more potent inducer for formamidase than formamide. However, even this greater amount of enzyme could not sufficiently compensate for the low activity with acetamide to yield a normal growth.

Valeramidase was induced when propionamide and longer-chain aliphatic amides served either as carbon or as nitrogen sources. It was subject to catabolite repression. The level of valeramidase decreased with increasing chain length when propionamide and longer acylamides served as carbon or nitrogen sources (Tables 3 and 4). The reaction rate, however, increased with increasing chain length. This inverse relationship between substrate specificity and enzyme level caused an amidase activity generating similar growth rates on different amides (Table 1). An inverse relationship between substrate and inducer specificity has been reported by Clarke \& Ornston (1975) for the acetamidase of Pseudomonas aeruginosa where propionamide was a better enzyme substrate than acetamide but a less efficient inducer. 
The activity ratios of formamidase and valeramidase of the mutants FH10 and FH11 with the aliphatic amides as substrates were similar to the ratio detected in the parent strain. It therefore seemed likely that the altered levels of amidase activity were not due to changes in the substrate specificity of the enzyme proteins, but to altered regulation of amidase formation. Strain FH10 formed formamidase constitutively in the absence of formamide. Valeramidase was not induced during growth with propionamide in this strain. The hydrolysis of propionamide by formamidase supplied the mutant with carbon, although at a rate insufficient to allow the growth rate to reach that attained by the parent strain on propionamide. This function of formamidase influenced the induction of valeramidase by propionamide in strain FH10 (Table 5). Propionamide hydrolysis by formamidase may have caused a decrease in the intracellular inducer concentration to a level insufficient to induce valeramidase. The inducer concentration is important for the rate of enzyme formation; this was demonstrated for the acetamidase of Pseudomonas aeruginosa (Brammar \& Clarke, 1964). The function of formamidase in $A$. eutrophus was limited by the regulation of enzyme formation. Although its reactivity with propionamide was slightly better than with acetamide, it was only induced by the latter amide. When the regulation of formamidase formation was altered by mutation and the enzyme synthesized constitutively, formamide and acetamide could serve as carbon sources for the mutant FH10. In this mutant formamidase could not be repressed by ammonia.

The acetamide-hydrolysing activity of valeramidase was sufficient to support growth on acetamide of the mutant FH11. Since valeramidase lacked formamide-hydrolysing activity, formamidase was induced in this mutant in addition to the semi-constitutive formation of valeramidase when formamide served as nitrogen source. When acetamide was present in the medium, strain FH11 formed valeramidase at a level 10-fold higher than the parent did with propionamide, its most potent inducer of valeramidase. This was evidence that the mutation of strain FH11 was a regulatory one changing the inducer specificity. Regulatory mutations leading to constitutive synthesis of one or more enzymes or to an altered inducer specificity have been reported for systems that involve the catabolism of substrates belonging to a homologous series. These mutations extended the aliphatic amide utilization of $P$. aeruginosa or caused resistance to carbon catabolite repression of the acetamidase of this strain as reviewed by Clarke \& Ornston (1975). In the more complex system of alkane utilization by Pseudomonas putida, these mutations were obtained by reversion of pleiotropic alk mutations (Fennewald \& Shapiro, 1977). Both systems have in common that they are involved in the carbon metabolism of the respective strains.

For Aspergillus nidulans a system was reported where two amidases were solely involved in nitrogen metabolism: (i) a specific formamidase not reacting with other amides and (ii) an acetamidase, most reactive with acetamide and less with longer-chain acylamides. However, the induction of formamidase and acetamidase was not specific and occurred with substrate and non-substrate amides in a similar ratio (Hynes \& Pateman, 1970).

The results obtained from regulatory studies with $A$. eutrophus suggest that the function of the two amidases in this organism is different. Formamidase appears to be involved in nitrogen metabolism since it was only formed when formamide and acetamide served as nitrogen sources and was repressed by ammonia. Valeramidase is involved in carbon metabolism. It is not repressed by ammonia but subject to carbon catabolite repression by succinate and fructose.

We thank K. Braun for the analysis of aliphatic acids by gas chromatography.

\section{REFERENCES}

Bowien, B., Mayer, F., Codd, G. A. \& Schlegel, H. G. (1976). Purification, some properties and quaternary structure of the D-ribulose 1,5diphosphate carboxylase of Alcaligenes eutrophus.
Archives of Microbiology 110, 157-166.

BRAMMAR, W. J. \& ClARKE, P. H. (1964). Induction and repression of Pseudomonas aeruginosa amidase. Journal of General Microbiology 37, 307-319. 
Chandra, T. S. \& Shetna, Y. I. (1977). Oxalate, formate, formamide, and methanol metabolism in Thiobacillus novellus. Journal of Bacteriology 131, 389-398.

Clarke, P. H. (1970). The aliphatic amidases of Pseudomonas aeruginosa. Advances in Microbial Physiology 4, 179-222.

Clarke, P. H. (1972). Biochemical and immunological comparison of aliphatic amidases produced by Pseudomonas species. Journal of General Microbio$\log y$ 71, 241-257.

Clarke, P. H. \& ORnSton, N. (1975). Metabolic pathways and regulation II. In Genetics and Biochemistry of Pseudomonas, pp. 263-340. Edited by P. H. Clarke \& M. H. Richmond. London: John Wiley.

FenNeWALD, M. \& SHAPIRO, J. (1977). Regulatory mutations of the Pseudomonas plasmid alk regulon. Journal of Bacteriology 132, 622-627.

FrIEDRICH, C. G., BOWIEN, B. \& FrIEDRICH, B. (1979). Formate and oxalate metabolism in
Alcaligenes eutrophus. Journal of General Microbio$\log y$ 115, 185-192.

GolDBERG, I. (1976). Bacterial yields on methanol, methylamine, formaldehyde and formate. Biotechnology and Bioengineering 18, 1657-1668.

HyNes, M. J. \& Pateman, J. A. (1970). The use of amides as nitrogen sources by Aspergillus nidulans. Journal of General Microbiology 63, 317-324.

LANG, E. \& LANG, H. (1972). Spezifische Farbreaktion zum direkten Nachweis der Ameisensäure. Zeitschrift für analytische Chemie 260, 8-10.

PEeL, D. \& QUAYLE, J. R. (1961). Microbial growth on $\mathrm{C}_{1}$-compounds. I. Isolation and characterization of Pseudomonas AM1. Biochemical Journal 81, 465469.

Schlegel, H. G., Kaltwasser, H. \& GotTschalk, G. (1961). Ein Submersverfahren zur Kultur wasserstoffoxidierender Bakterien: Wachstumsphysiologische Untersuchungen. Archiv für Mikrobiologie 38, 209-222. 